\title{
Responses of Sediment Properties to Paleoclimatic Changes since the Holocene in Ancient Milan River Channel, Northwest China
}

\author{
HuiLing Wang ${ }^{1}$, Tursun Kasim ${ }^{1}$, Aishajiang Aili ${ }^{2 *}$ \\ ${ }^{1}$ College of Resources and Environmental Science, Xinjiang University, Urumqi, 830046, China \\ ${ }^{2}$ State Key Laboratory of Desert and Oasis Ecology, Xinjiang Institute of Ecology and Geography, \\ Chinese Academy of Sciences, Urumqi 830011, China
}

Received: 9 February 2021

Accepted: 27 April 2021

\begin{abstract}
In this paper, the sediment grain size, organic matter $\mathrm{C} / \mathrm{N}$ ratio, and isotope $\delta^{13} \mathrm{C}$ of the ancient Milan River channel, Northwest China are used as indicators, and their responses to paleoclimatic changes since the Holocene were analyzed. The results show that the dominant grain size of the surface sediments of the ancient Milan River channel is silt, and the soil particle size is smaller than that of the floodplain, indicating that the hydrodynamics were weak in the late paleochannel. The surface sediments of the paleochannel contain a wind created layer of sand, indicating that the sedimentary environment was affected by a two-phase function of wind and water. The $\mathrm{C} / \mathrm{N}$ ratio of the sediments varies from 5 to 19.6 with an average value of 12.3 . The $\delta^{13} \mathrm{C}$ values range from $-27.383 \%$ to $21.58 \%$, indicating that the organic matter in the sediment was dominated by river organic matter but mixed with some terrestrial organic matter. The dates of the Optically Stimulated Luminescence (OSL) and the variation in the measured values of each element in the vertical section indicate that since $5000 \mathrm{aBP}$, the paleoclimate in the study area has experienced six stages of evolution. In stage I, 5000-4500 aBP, the climate was mainly warm and dry. During this period, the climate environment fluctuated frequently, and the cold and warm periods alternated. During stage II, 4500-3900 aBP, the climate gradually decreased and then rebounded slightly. The overall climate was cold and humid, and the water volume increased significantly during this period. During stage III, 3900-2800 aBP, the climate experienced a large temperature increase and cooling, and a warm front appeared around $3000 \mathrm{aBP}$, indicating typical warm and dry climate characteristics during this period. In stage IV, 2800-1800 aBP, the temperature continued to decrease, and the climate became cold and humid, which was conducive to the growth of crops. In stage V, the first half of the period from 1800 to $1000 \mathrm{aBP}$ was relatively warm and dry, and the temperature dropped briefly causing a cold period. In stage VI, $1000 \mathrm{aBP}$ to present, the temperature experienced a small fluctuation, the climate became dry and
\end{abstract}

*e-mail: aishajiang@ms.xjb.ac.cn 
cold, and the climate and environmental characteristics have entered a relatively warm and dry period.

This study helps us to understand the land degradation and desertification processes in arid area.

Keywords: Paleoclimate, ancient river channel, sediments, organic matter, isotope, Milan River

\section{Introduction}

Particle size is a parameter that reflects the size of sediment particles. It is the most important structural feature of the particles in sediments. It is controlled by various factors, such as the handling medium and handling method, and is closely related to the sedimentary environment and hydrodynamic conditions [1-5].

The sediment $\mathrm{C} / \mathrm{N}$ ratio and $\delta^{13} \mathrm{C}$ content are organic geochemical indicators that are commonly used in paleoclimatic research. They are good indicators of paleoclimate and paleoecological information [6-8]. It can reflect the primary productivity of the basin and the preservation of organic matter in the sedimentary environment [9-11]. It can also indicate the source of ancient vegetation and the source of the organic matter in the sediment [12-16]. The information it reflects is rich, but there are also complexities and multiple solutions in paleoclimatic interpretation [17-20].

The arid zone in northwestern China is located at the intersection of the westerly and monsoon regions, and it contains extensively developed inflow rivers and inland lakes [21-24]. In addition, the climate in the arid regions of northwestern China varies significantly with geographical location. Numerous domestic and foreign scholars have studied the ancient climate of Lop Nur [25-28]. For example, using the calcium mirabilite inclusions in the Lop Nur Salt Lake to study the Late Pleistocene paleoclimate and using the lake sediments to study the Quaternary environmental evolution [29-31]. However, due to the lack of paleoclimate reconstruction in the Milan River Basin, in this paper, we study the Milan River, which originates from the Altun Mountains and is located in the hinterland of Eurasia. It is a typical inland river. The ancient river channel effectively recorded the environmental surrogate indicators. We use high-precision measurements of these indicators to quantitatively extract the climateenvironmental information, to reconstruct the sequence of past environmental changes in the region, and to enhance our understanding of the region's historical climate, which also reveals information about the future climate. This prediction of environmental change provides a theoretical basis for optimizing the living environment of human beings.
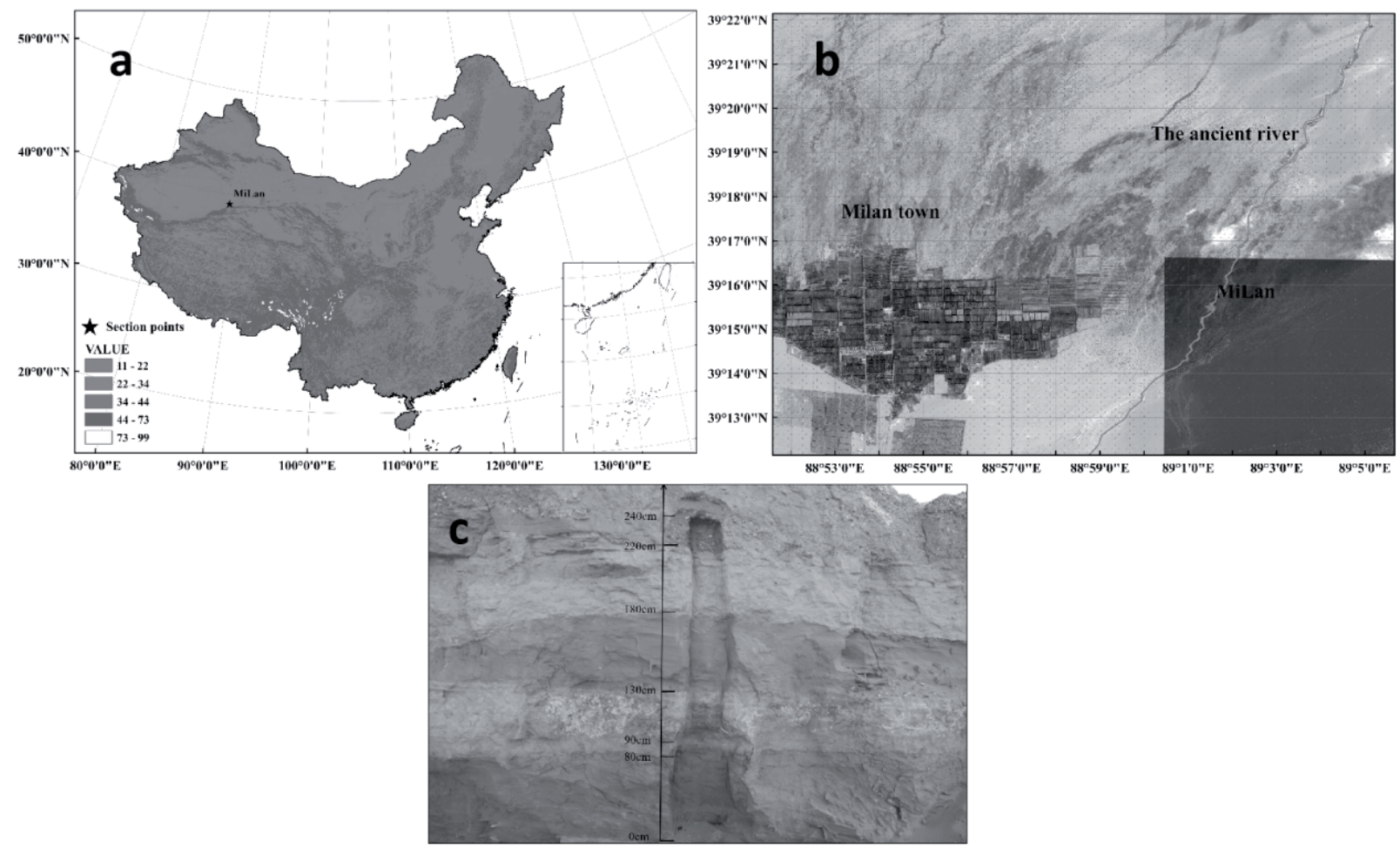

Fig. 1. a) Location of the Milan River in northwestern China. Solid dots represent the study area. This map shows the geomorphological features of China. b) Distribution and profile location of the ancient river channel of the Milan River. c) Schematic diagram of the natural profile of the Milan River. 


\section{Materials and Methods}

\section{Study Area}

The Milan River Basin is located between $88^{\circ} 30^{\prime}-89^{\circ} 44^{\prime} \mathrm{E}$ and $38^{\circ} 10^{\prime}-39^{\circ} 30^{\prime} \mathrm{N}$ (Fig. 1). It is bordered by the Altun Mountains to the south, the Lop Nur in the Tarim Basin to the north, the Ruoqiang River to the west, and the Kumutage Desert to the east. It is located in a typical continental warm temperate zone. The warm and humid airflow from India is blocked by the Altun Mountains. It is difficult to enter the region. The water vapors from the Atlantic Ocean and the Pacific Ocean have to travel long distances to reach this region. The oasis in Milan has been left behind, and it is difficult to form precipitation due to the desert drought.

The Milan River originates from Eyupup Aretage Peak at an altitude of $6161 \mathrm{~m}$ in the eastern part of the Altun Mountains. The mountainous area has snow all year round. There are modern glaciers in the upper reaches of the basin. The drainage area is $5791 \mathrm{~km}^{2}$, of which the catchment area of the mountain area accounts for $71 \%$ of the total area of the basin. The plain area accounts for $29 \%$ of the total area of the basin. The history of the Milan River Basin was once the jurisdiction of YiXun City in the Western Region of China during the Western Han Dynasty [32].

The Milan River Basin can be divided into two geomorphic units in the north and the south with the northern part of the river as the boundary. The northern section is the alluvial sloping plain, and the south is the middle and high mountains. The mountainous area lacks vegetation, and only low-lying shrubs such as sparse willows grow on both sides of the river. The upper part of the alluvial sloping plain is a thick gravel pebble layer. The lower fine soil plain is composed of sandy loamy soil. The surface is scattered with fixed or semi-fixed red willow sandbags. Due to the supply of river water, a small oasis has formed. The main vegetation is Red Willow, Haloxylon.

\section{Sample Collection}

In October 2018, we investigated the natural section of the ancient river channel in Milan, Ruoqiang County, Xinjiang, ML $\left(88^{\circ} 59^{\circ} \mathrm{E}, 39^{\circ} 13^{\prime} \mathrm{N}\right)$. The selected section is located about $2 \mathrm{~km}$ south of the ancient city of Milan, the riverbed is roughly $30 \mathrm{~m}$ in cross section, and the section consists of six distinct soil layers. Four dating samples and 54 indicator samples were collected.

We conducted an OSL (Optically Stimulated Luminescence) dating analysis of four samples at the Optically Stimulated Luminescence Time Laboratory at Nanjing University. The depth-age sequence of the soil layer was established [33-35].

\section{Experimental Analysis}

The particle size measurement was performed at the Central Laboratory of Xinjiang Institute of Ecology and Geography, Chinese Academy of Sciences using a Mastersiez2000 laser particle size analyzer from MALVERN, UK. The measurement range of the instrument is $0.01-1000 \mu \mathrm{m}$. The sample processing steps are as follows: place about $0.8 \mathrm{~g}$ of sample in the beaker, add $10 \mathrm{~mL}$ of $10 \% \mathrm{H}_{2} \mathrm{O}_{2}$, heat the mixture on the hot plate until the reaction is complete, add $10 \mathrm{~mL}$ of $10 \% \mathrm{HCl}$ and $10 \mathrm{~mL}$ of water, let the mixture stand for $12 \mathrm{~h}$, wash the mixture with water; and finally, add $10 \mathrm{~mL}$ of about $0.5 \mathrm{M}$ sodium $\left[\mathrm{NaPO}_{3}\right]_{6}$ as a dispersing agent. After the resulting mixture was shaken, it was analyzed on the machine. After the analysis was completed, the laser particle size analyzer automatically reported the index of each fraction of the sample, the median diameter, the average particle diameter, and the frequency curve. The particle size classification of the sediments is based on the Udden-Wentworth scheme, which is widely used internationally. The sediment particle size is divided into 8 grades, i.e., clay of less than $3.9 \mu \mathrm{m}, 3.9-7.8 \mu \mathrm{m}$ fine sand, 7.8-15.6 $\mu \mathrm{m}$ fine silt;, medium silt 15.6-31.2 $\mu \mathrm{m}$, coarse silt 31.2-62.5 $\mu \mathrm{m}$, very fine sand $62.5-125 \mu \mathrm{m}$, fine sand $125-250 \mu \mathrm{m}$, and medium coarse sand of more than $250 \mu \mathrm{m}$ [36-38].

The elemental analysis was completed at the Central Laboratory of the Xinjiang Institute of Ecology and Geography, Chinese Academy of Sciences. The vacuum freeze-dried samples were ground to a powder size of about 80 mesh, packaged in a tin capsule, and sent directly to an EA 3000 (Euro Vector, Italy) elemental analyzer for total nitrogen (TN) measurement [39]. An appropriate amount of lyophilized sample was placed into a standard silver cup, 2 drops of $5 \% \mathrm{HCl}$ were added, the mixture was placed on a $60^{\circ} \mathrm{C}$ hot plate for $2 \mathrm{~h}, 1-2$ drops of $\mathrm{HCl}$ were added, the hot plate was adjusted to $40^{\circ} \mathrm{C}$, and the sample was heated until it evaporated. After this, the tin capsule was packaged, and it was analyzed using an EA 3000 (Euro Vector, Italy) elemental analyzer to determine the organic carbon $[40,41]$.

A certain amount of lyophilized ground sediment sample was added to $10 \%$ dilute hydrochloric acid to remove the carbonate in the sample, and then, the sample was repeatedly washed with deionized water, air dried, and ground to less than 80 mesh. A certain amount of sample was weighed and packed in a tin capsule. After burning the sample in a Flash 2000 organic elemental analyzer, the gas was sent to a Thermo Scientific isotope mass spectrometer to determine the $\delta^{13} \mathrm{C}$ [42-43]. The analysis was conducted at the Central Laboratory of the Xinjiang Institute of Ecology and Geography, Chinese Academy of Sciences. 


\section{Results}

\section{Profile of Depositional Characteristics and Chronological Sequence Establishment}

The ML section is located about $2 \mathrm{~km}$ northwest of the ancient city of Milan. It is a natural section of the northeastern part of the ancient Milan River channel. The depth of the entire section is $280 \mathrm{~cm}$, and the sediments are mainly composed of clay, silt, and sticky silt strips of different colors. The ML profile can be divided into 6 natural sedimentary layers from top to bottom according to the different depositional characteristics, as shown in Fig. 2.

(1) Depth of 0-70 cm, grayish gravel layer.

(2) Depth of 70-110 cm, yellow-brown clay layer.

(3) Depth of 110-160 cm, grayish yellow fine sand and thin silt.

(4) Depth of 160-200 cm, brown clay accompanied by an alkaline soil layer.

(5) Depth of 200-210 cm, green muddy silty sand.

(6) Depth of $210-280 \mathrm{~cm}$, taupe fine sand layer.

The establishment of the ML typical profile chronological sequence was mainly conducted using the OSL dating method. Four OSL years were determined for the clay-sand paleosol with $96,134,157$, and $235 \mathrm{~cm}$ profiles. The age of the OSL is $2.64 \pm 0.26$ to $4.89 \pm 0.47 \mathrm{ka}$, which corresponds to the depth of the formation within the error range, indicating that the selected section of sediment was deposited since the Holocene.

\section{Particle Size Analysis}

(1) Particle size frequency distribution curve. The particle size frequency distribution curve can be used to describe the overall characteristics of the sample and can more intuitively show the relative content of each particle size within the sample and its contribution to the total sample, and the origin of the sample can be identified according to the curve morphological characteristics [44-46]. There are three main types of surface particle size frequency curves for the paleochannel of the Milan River (Fig. 3): Single kurtosis, double kurtosis, and multi-kurtosis. The single-peak distribution curve shown in Fig. 3a) has obvious aeolian sand characteristics. There are 7 samples, which are mainly evenly distributed in the upper layer. The particle size frequency curves of the 36 sediment samples from the middle of the section show a bimodally distribution, and the upper and lower layers of the section are also evenly distributed. Fig. 3b) shows the bimodally distribution of the river sediments, which can be further divided into two types, one of which is shown in Fig. 3b). The first kurtosis is not prominent enough, but the other is the first kurtosis peak of the granularity frequency curve. It is significantly different from the peak value of the second kurtosis state, and there is a significant difference in the value of the grain size between the two kurtosis states. The particle size distribution curves of 30 samples out of 36 samples are not as prominent as the first peak kurtosis (Fig. 3b), but the peak distributions of the samples are relatively concentrated at $0.1-1 \mu \mathrm{m}$, which is the clay component. The peak values of the two peaks varied greatly, mostly within the silt size range, with an average percentage of $47 \%$ and an average clay content of $5.67 \%$. The sediment particle size frequency curves of the remaining 9 samples exhibit multimodality, and the maximum peak was located near $70 \mu \mathrm{m}$, indicating that there was finer sand, and the average

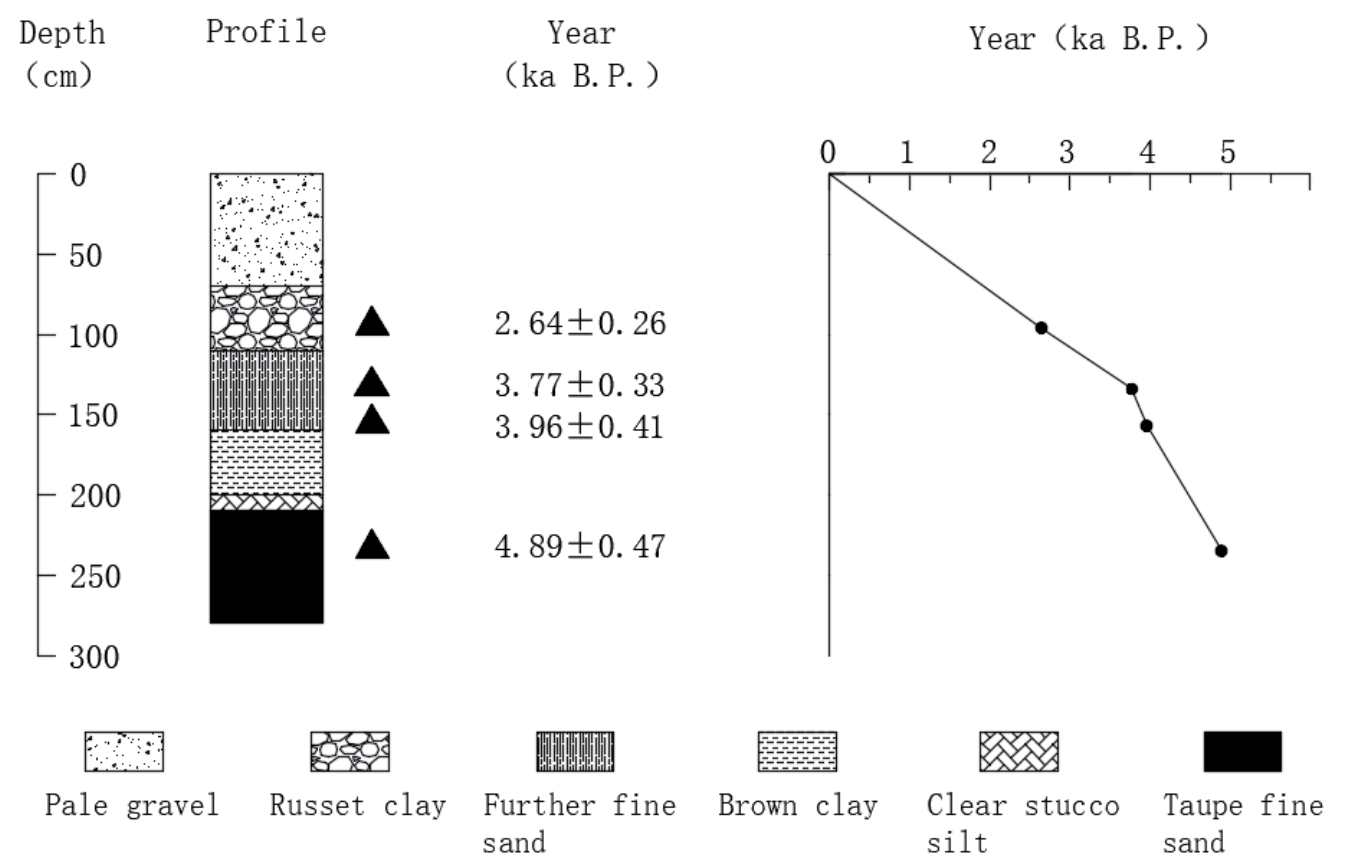

Fig. 2. Sedimentary characteristics and age-depth relationship of the Milan River. 

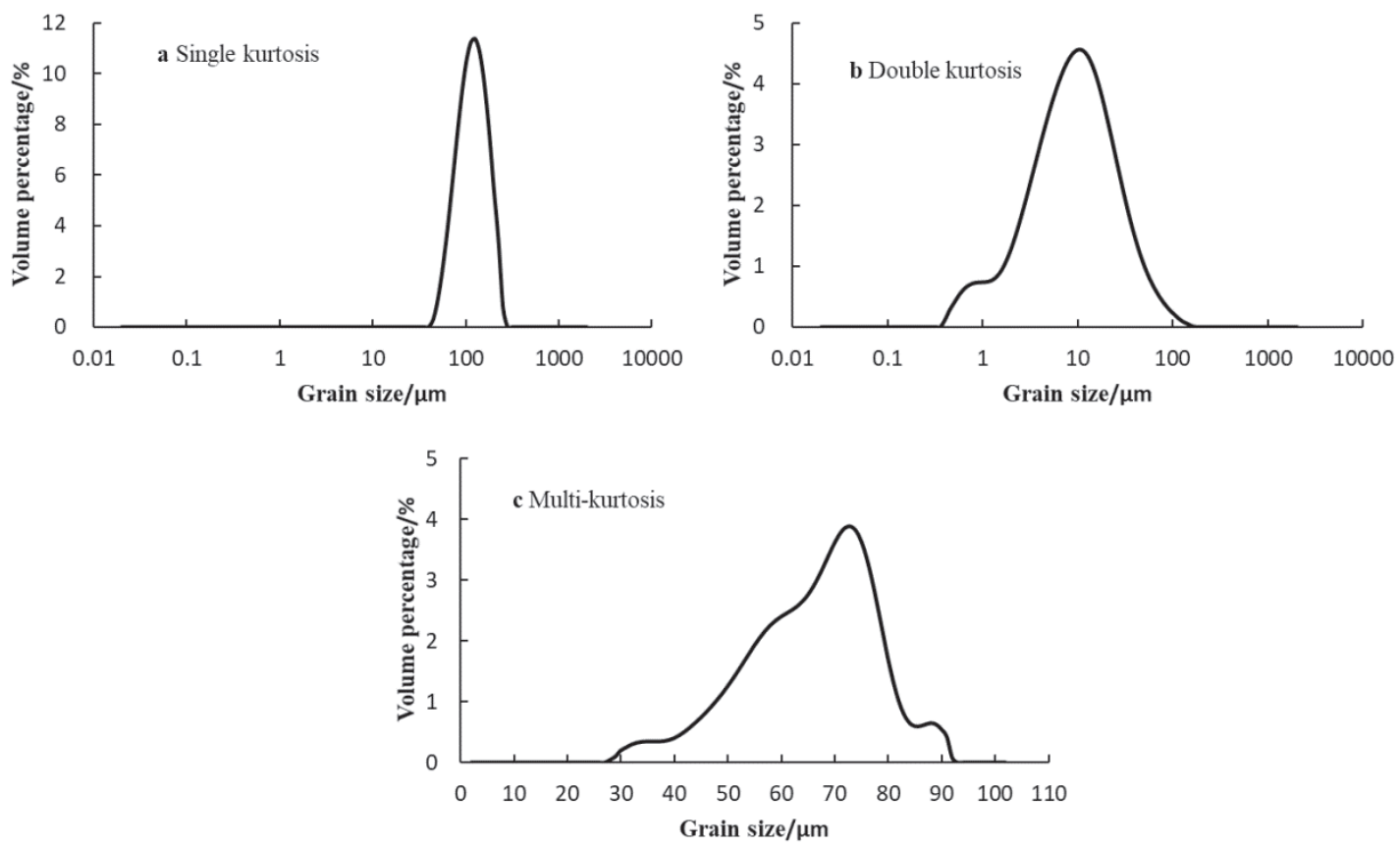

Fig. 3. Types of particle size distribution curves of the surface sediments in the ancient Milan River channel. a) Single kurtosis type. b) Double kurtosis type. c) Multi-kurtosis type.

percentage was about $42.23 \%$. We eliminated two clearly erroneous samples. Based on the characteristics of the size distribution curves of 54 samples, 7 samples are unimodal, indicating aeolian sand accumulation; 36 samples are bimodal, indicating river sediment; and 9 are multi-modal, indicating river sediment.

(2) Granularity parameters. For $\Phi=-\log 2 \mathrm{~d}$ (d indicates the particle size of the deposit in $\mathrm{mm}$ ), after the particle size measurement result is converted into the equal ratio granulation level $\Phi$, the average particle size $\mathrm{M}_{\mathrm{z}}$ is calculated according to the Flock-Ward formula, and the sorting coefficient $\sigma_{1}$ is obtained (kurtosis KG and skewed $\mathrm{SK}_{1}$ ). Both the average particle size and the median particle size can be used to reflect the average particle size of the sediment, which is a reflection of the average kinetic energy of the operating force [4749].In the surface sediments of the ancient Milan River channel, the average particle size of the aeolian sand is relatively large, ranging from 0.15 to $0.176 \mathrm{~mm}$ with a mean value of $0.163 \mathrm{~mm}$. The average grain size of the river sediment varies significantly from 0.01 to $0.295 \mathrm{~mm}$, but for most of the samples, the average particle size is $<0.05 \mathrm{~mm}$, and the average particle diameter is smaller than that of the aeolian sand particles. Since the median diameter $d_{50}$ is the particle size when the frequency of the particle size frequency accumulation curve is $50 \%$, it exhibits the same distribution characteristics as the average particle diameter.

(3) Sediment $\mathrm{C} / \mathrm{N}$ ratio. Vertical distribution characteristics of the $\mathrm{C} / \mathrm{N}$ ratio of the sediment.

$\mathrm{The} \mathrm{C} / \mathrm{N}$ ratio of the organic matter in the sediments of the ancient Milan River is vertically distributed.
As can be seen in Fig. 4, the $\mathrm{C} / \mathrm{N}$ ratio of the organic matter the sediments is 5-20 but mainly falls within the range of 5-15. (1) The vertical distribution curve of the sediment $\mathrm{C} / \mathrm{N}$ ratio fluctuates sharply. It is stable only in the middle layer from 100 to $150 \mathrm{~cm}$. It reached the highest value of 19.6 at a depth of $200 \mathrm{~cm}$ in $4500 \mathrm{aBP}$, and the lowest value at a depth of $80 \mathrm{~cm}$ in $2500 \mathrm{aBP}$. The average value was 12. (2) The $\mathrm{C} / \mathrm{N}$ ratio was relatively low at 5000-4500 aBP, with strong fluctuations, ranging from 5.6 to 16.2 and an average of 10.9. The ratio at 4500-3900 aBP was relatively high, ranging from 8.9 to 19.6 with an average of 14.25. The ratio at $3900-2800$ aBP was relatively stable, ranging from 7.3 to 11 with an average of 9.15 . At $2800-1800 \mathrm{aBP}$, the sediment $\mathrm{C} / \mathrm{N}$ ratio initially increased, then decreased, and finally dropped to the lowest point at 1800 aBP with a value of 5 . At $1800-1000 \mathrm{aBP}$, the sediment $\mathrm{C} / \mathrm{N}$ ratio increased with an average value of 14.15. From $1000 \mathrm{aBP}$ to present, the sediment $\mathrm{C} / \mathrm{N}$ ratio fluctuated sharply, and the average value of the ratio was 12.55 .

(4) Organic carbon $\delta^{13} \mathrm{C}$ analysis. Vertical distribution characteristics of the sediment $\delta^{13} \mathrm{C}$ content. As can be seen in Fig. 4, the vertical distribution curve of the $\delta^{13} \mathrm{C}$ content of the sediments of the ancient Milan River is relatively intense and is only stable from 50 to $100 \mathrm{~cm}$. The $\delta^{13} \mathrm{C}$ content of the sediment is relatively large at $5000-4500 \mathrm{aBP}$, the fluctuation range is $-26.544 \%$ to $-23.912 \%$, and the average value is $-25.228 \%$. In the middle of the 4500-3900 aBP period, the fluctuation is small, with a range of $-27.128 \%$ o to $-25.034 \%$ and an average of $-26.081 \%$. The $3900-2800$ aBP is relatively large and fluctuates violently, ranging from $-26.424 \%$ o 


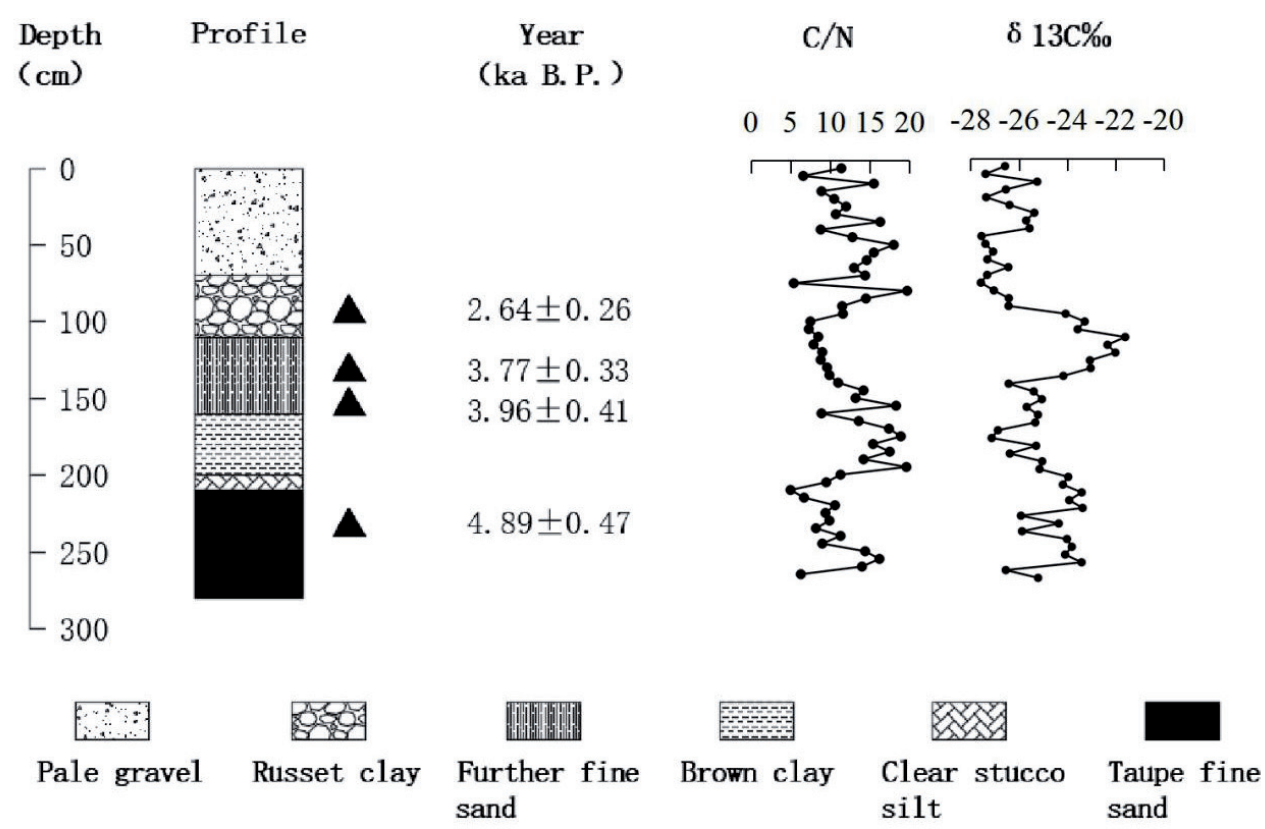

Fig. 4. $\mathrm{C} / \mathrm{N}$ curve and $\delta^{13} \mathrm{C}$ content of the Milan River section.

to $-21.88 \%$ with an average of $-24.006 \%$, exhibiting a trend that gradually decreases and then decreases. From 2800 to $1800 \mathrm{aBP}$, the $\delta^{13} \mathrm{C}$ content of the sediment gradually decreased, with an average value of $-26.728 \%$. At $1800-1000$ aBP, the sediment $\delta^{13} \mathrm{C}$ content slightly increased, the average value was $-26.754 \%$, and the change was relatively small. The $\delta^{13} \mathrm{C}$ content at $1000 \mathrm{aBP}$ fluctuated frequently, ranging from $-27.383 \%$ to $-25.24 \%$ with an average of $26.311 \%$.

\section{Discussion}

\section{Sedimentary Environment of the Ancient Milan River Channel}

The particle size distribution of the sediment is mainly controlled by factors such as the transport medium, the handling mode, and the deposition environment. Therefore, the sedimentary environment in which the sediment was deposited can be understood by studying the sediment particle size distribution [5053]. The surface sediments of the ancient Milan River channel collected in this study are mainly composed of 6 types of sediment: fine slit, fine silt sand, medium silt sand, coarse silt sand, very coarse silt sand, and very fine sand. Most of the skewness is extremely positive or positive, and the peak state is narrower, indicating that the surface sediment particles are finer and the fine particle components are concentrated. This is consistent with the study of the particle size analysis of the Holocene surface sediments in the middle and lower reaches of the Tarim River, which found that the main component is silt. The hydrodynamics in the late riverbed of the ancient Milan River channel are obviously weaker than those of the flood plain in the flooding period of the river, and only the weak water flow carrying the fine particles such as silt and clay passed.

Each particle size parameter has a certain genetic origin and sedimentary environment discrimination significance [54-56]. The particle size measurements of the samples collected from the ancient Milan River channel distribution area show that there is aeolian sand accumulation in the sample, but the sediment size is mainly silt. The sub-class composition only shows the differentiation of the aeolian sand and river sediments. The first-class component of the aeolian sand is fine sand, while the river sediment is clay. In the later period, the river had a smaller water flow, and the finegrained sediments piled up and buried the sand layer. Our result is consistent with previous studies. Zhao et al. analyzed the historical change of carbon burial in late quaternary sediments of the ancient Yellow River delta on the west coast of Bohai Bay, northern China, and indicated that climate may affect the dynamics of carbon burial by regulating terrestrial inputs [57]. The action process is shown in the late stage, and the river sedimentary environment is affected by the combined action of wind and water. This result would be helpful to understand the variation of hydrological processes in ancient river basin.

The Main Controlling Factors of the Change in the $\mathrm{C} / \mathrm{N}$ ratio of the Sediments and the

Significance of the Paleoclimatic Environment

The $\mathrm{C} / \mathrm{N}$ ratio of the sediment is an effective indicator of the source of organic matter [58, 59]. The ratio of endogenous and exogenous organic matter can be distinguished based on the difference in the sediment's organic matter and its $\mathrm{C}$ and $\mathrm{N}$ compositions 
$[60,61]$. It is generally believed that when $\mathrm{C} / \mathrm{N}>10$, the sediment's organic matter is mainly exogenous; when $\mathrm{C} / \mathrm{N}<10$, the endogenous organic matter is dominant; and when $\mathrm{C} / \mathrm{N} \approx 10$, the exogenous and endogenous organic matter are basically in equilibrium. The $\mathrm{C} / \mathrm{N}$ ratio of the sediments in the ancient Milan River channel indicates that the source of the organic matter is the input of aquatic lake organisms and terrestrial sources, of which the external input is slightly dominant. At $5000-4500 \mathrm{aBP}$, the sediment $\mathrm{C} / \mathrm{N}$ ratio was 10.9 , the organic matter was mainly from a land source, and the river productivity was high. At 4500-3900 aBP, the sediment $\mathrm{C} / \mathrm{N}$ ratio is relatively large $(14.25)$, and the organic matter is mainly from a land source, indicating that the river productivity is high during this period and the water flow was sufficient, so that the terrestrial organic matter near the river channel is an input. Variation of water flow may also impact the sediment characteristics. This result is also consistent with previous research. $\mathrm{Xu}$ et al. analyzed the sedimentary facies and depositional processes of the Diexi Ancient Dammed Lake, Upper Minjiang River, China, and indicated that the flood carried a large amount of sediments into the lake, and the decelerating flow generated successively alternating layers of gravels and sand [62]. At 2800-3900 aBP, the sediment $\mathrm{C} / \mathrm{N}$ ratio was close to 10 , and the change was stable, indicating that the exogenous and endogenous organic matter were basically in equilibrium during this period. The $\mathrm{C} / \mathrm{N}$ ratio of the sediments at 2800-1800 aBP increased gradually and then decreased, and the variation range was large, indicating that the river flow was unstable, and there was an interruption in the current. From 1800-1000 aBP, the sediment $\mathrm{C} / \mathrm{N}$ ratio had a small amplitude. Due to these drastic fluctuations, river productivity was unstable during this period, and the sediment sources were more complicated.

\section{Main Factors Controlling the $\delta^{13} \mathrm{C}$ Content Change and Paleoclimatic Environmental Significance}

The difference in the source of organic matter in the sediment affects the $\delta^{13} \mathrm{C}$ value [63]. Usually, the carbon isotope composition reflects the kinetics of the carbon assimilation during photosynthesis of the different organisms and the isotopic carbon composition of the carbon source [64]. A large number of studies have found that the typical $\delta^{13} \mathrm{C}$ value of aquatic organisms is $-19 \%$ to $-22 \%$, and the $\delta^{13} \mathrm{C}$ value of typical terrestrial plant organic matter is $-26 \%$ to $-28 \%$ [65].

Fig. 4 shows that the $\delta^{13} \mathrm{C}$ value of the sediments of the ancient Milan River channel is between $-21.588 \%$ and $-27.55 \%$, which falls between the stable carbon isotope ratios of aquatic organisms and terrestrial plant organic matter, indicating that the organic matter in the sediments in the study area is a mixture of river sediment organic carbon and terrestrial organic carbon. This is consistent with the conclusions obtained from the $\mathrm{C} / \mathrm{N}$ ratio.
The difference in the stable carbon isotopes of the terrestrial organic matter is due to the different biochemical pathways used in plant photosynthesis. Emerson and Hedges (1988) found that the $\delta^{13} \mathrm{C}$ value of terrestrial $\mathrm{C}_{3}$ plant organic carbon is $-26 \%$ to $-28 \%$; while for plants that use $\mathrm{C}_{4}$ (Hatch Slack) to synthesize carbon, the average value of $\delta^{13} \mathrm{C}$ of the organic carbon produced is $-14 \%$. $\mathrm{C}_{3}$ plants mainly grow in low temperature, humid environments, while $\mathrm{C}_{4}$ plants mainly grow in relatively dry, high temperature environments [66].

Changes in sediment $\delta^{13} \mathrm{C}$ values can reflect changes in terrestrial organic matter and river organic matter input as well as changes in terrestrial vegetation types, especially $\mathrm{C}_{3}$ and $\mathrm{C}_{4}$ relative biomass [67]. Although there are many environmental factors that can affect the relative yields of $\mathrm{C}_{3}$ and $\mathrm{C}_{4}$ plants, atmospheric temperature and precipitation are thought to be the main factors affecting the competition between $\mathrm{C}_{3}$ and $\mathrm{C}_{4}$ plants [68].

In theory, when temperature increases and precipitation decreases, $\mathrm{C}_{4}$ plants are more competitive, so $\delta^{13} \mathrm{C}$ is positive; when temperature decreases and precipitation increases, and the $\mathrm{C}_{3}$ plants increase and the $\delta^{13} \mathrm{C}$ value is negative. Fig. 4 shows that the $\delta^{13} \mathrm{C}$ value $(-25.228 \%$ o $)$ of the sediments in the ancient Milan River channel is close to the stable carbon isotope value of terrestrial plant organic matter at 5000-4500 aBP. The climate in this area was mainly humid and warm during this period, with more land-based vegetation and vegetation surrounding the river.

At 4500-3900 aBP, the temperature began to increase, $\mathrm{C}_{3}$ plants were more competitive, and the $\mathrm{C}_{3}$ plant organic matter input increased in the sediments. From 3900 to $2800 \mathrm{aBP}$, the $\delta^{13} \mathrm{C}$ value of the sediment gradually decreased in the vertical section, and the variation range was large. The climate change was large. The $\delta^{13} \mathrm{C}$ value of the sediment $(-24.006 \%$ ) was between that of aquatic organisms and that of terrestrial organisms. This indicates that the sediment source was more complicated at this time, which is basically consistent with the conclusion obtained from the $\mathrm{C} / \mathrm{N}$ ratio.

At 2800-1800 aBP, the $\delta^{13} \mathrm{C}$ value decreased significantly, reaching the lowest temperature value around $1800 \mathrm{aBP}$, indicating that this period was cold, and the main organic matter input was from $\mathrm{C}_{3}$ plants. From 1800 to $1000 \mathrm{aBP}$, the $\delta^{13} \mathrm{C}$ value rebounded slightly and the change was stable. From 1000 aBP to present, the $\delta^{13} \mathrm{C}$ value of the sediments increased significantly, indicating that the climate entered a new heating period.

\section{Conclusions}

As can be seen from the analysis, the dominant grain sizes of the surface sediments of the ancient Milan River channel were fine silt sand, fine silt sand, 
medium silt sand, coarse silt sand, very coarse silt sand, and very fine sand. The changes in the average particle size $M_{z}$, the sorting coefficient $\sigma_{1}$, the kurtosis $K G$, and the skewed $\mathrm{SK}_{1}$ all indicate that the surface sediment particles were fine and concentrated. The characteristics of the particle size frequency distribution curve indicate that there is a wind-blown sand accumulation layer in the surface sediments of the ancient Milan River channel. This indicates that in the late stage, the flow of the ancient rivers was interrupted, and the sedimentary environment was affected by the interaction of wind and water.

The $\mathrm{C} / \mathrm{N}$ ratio and $\delta^{13} \mathrm{C}$ of the sediments in the ancient Milan River channel confirm changes in the environment. Since $4500 \mathrm{aBP}$, the overall climate in the study area has been relatively warm and dry, but there have been several short wet and cold periods. The climate can be roughly divided into six stages. In stage I, 5000-4500 aBP, the climate was mainly characterized by warm and dry weather. During this period, the climate fluctuated frequently, and the cold and warm periods alternated. In stage II, 4500-3900 aBP, the climate gradually decreased, and then, it rebounded slightly. The overall climate was cold and humid, and the water volume increased significantly during this period. In stage III, 3900-2800 aBP, the climate experienced a large temperature increase and cooling.

The warm front appeared around $3000 \mathrm{aBP}$, and the area was characterized by typical warm and dry climate. In stage IV, 2800-1800 aBP, the temperature continued to decrease, and the climate became cold. Moisture is conducive to the growth of crops. In stage V, 1800-1000 aBP, it was relatively cold and humid, with a brief temperature increase in the middle. In stage VI, $1000 \mathrm{aBP}$ to present, the temperature experienced a small fluctuation, the climate became cold and dry, and the climate entered a relatively warm and dry period.

\section{Acknowledgments}

This study was jointly supported by National Natural Science Foundation (41761046) and Western Light Foundation of Chinese Academy of Sciences (Y734341). We are grateful to the Prof. Mu Guijin from Xinjiang Institute of Ecology and Geography, Chinese Academy of Sciences for guiding the field sample collection and the particle size analysis of the samples. We also thank Professor Zhang Feng from the College of Resources and Environmental Sciences of Xinjiang University for his assistance in the data collection.

\section{Conflict of Interest}

The authors declare no conflict of interest.

\section{References}

1. FAN X.Q., WANG G.W., LI Y.F., DAI Q.Q., SONG L.H., DUA N.C.W., ZHANG C.G., ZHANG F.S. Pore structure evaluation of tight reservoirs in the mixed siliciclastic-carbonate sediments using fractal analysis of NMR experiments and logs. Mar. Petrol. Geol. 109, 486, 2019.

2. LEI X.,LI X.G., WEI N. Fractal features of soil particle size distribution in layered sediments behind two check dams: Implications for the Loess Plateau, China. Geomorphology, 266 (1), 134, 2016.

3. YIN Z.Q., QIN X.G., WU J.S. Study on multi-component characteristics of lake sediment grain size and its genetic mechanism. Quaternary study, 28, 348. 2008.

4. ZHI W.B., ZHEN J.Y., JIAN M.X. Grain-size characteristics and sediment environment of Quaternary sediments in the central Tarim basin. Arid Land Geogr. (in Uighur language), 32, 338, 2009.

5. LONG M.A., ABUDUWAILI J. Grain Size Characteristics and Its Environmental Significance of Lacustrine Sediment Recorded in Wuliangsu Lake, Inner Mongolia. Acta Sediment. Sinica, 34, 259, 2013 [In Chinese].

6. ZHAO Y., WU F., FANG X.. Topsoil $\mathrm{C} / \mathrm{N}$ ratios in the Qilian Mountains area: Implications for the use of subaqueous sediment $\mathrm{C} / \mathrm{N}$ ratios in paleo-environmental reconstructions to indicate organic sources. Palaeo-geogr., Palaeo-cli, Palaeo-ecol 44, 431, 2015.

7. CONTRERAS S., WERNE J.P., ARANEDA A. Organic matter geochemical signatures (TOC, TN, C/N ratio, $\delta^{13} \mathrm{C}$ and $\delta^{15} \mathrm{~N}$ ) of surface sediment from lakes distributed along a climatological gradient on the western side of the southern Andes. Sci. Total Environ, 630, 882, 2018.

8. MERLIN L., TIIU A., LEELI Al. Late glacial and early Holocene climate and environmental changes in the eastern Baltic area inferred from sediment $\mathrm{C} / \mathrm{N}$ ratio. $\mathrm{J}$. Pale limnology, 38, 249, 2018.

9. SERGIO C., JOSEF P., WERNE A., ARANEDA R., URRUTIA C.A. Organic matter geochemical signatures (TOC, TN, C/N ratio, $\delta^{13} \mathrm{C}$ and $\delta^{15} \mathrm{~N}$ ) of surface sediment from lakes distributed along a climatological gradient on the western side of the southern Andes. Sci.Total. Environ. 630 (15), 779, 2018.

10. PATRICIA A., CORBETT C. K., JULIE A.M. Tracking spatial distribution of human-derived wastewater from Davis Station, East Antarctica, using $\delta^{15} \mathrm{~N}$ and, $\delta^{13} \mathrm{C}$ stable isotopes. Mar.Pollut.Bull. 90 (1-2), 44, 2015.

11. HE J.H., YU W., CHEN L.Q., WU M. Characters of the Organic $\delta \sim(13) \mathrm{C}$ and Its Climatic Information in Sediment Cores of the Lakes Nearby the Arcitic Yellow River Station of China. J. Isotopes, 25, 169, 2012.

12. ADRIAN M.B., ROBERT C.W., MATTHEW R. Testing the use of bulk organic $\delta^{13} \mathrm{C}, \delta^{15} \mathrm{~N}$, and Corg:Ntot ratios to estimate subsidence during the 1964 great Alaska earthquake. Quat.Sci.Rew.113 (12), 137, 2015.

13. FEDERICO Di.R., FLAVIA M.,MARCO S. Late Holocene environmental dynamics, vegetation history, human impact, and climate change in the ancient Literna Palus (Lago Patria, Campania, Italy). Rev Palaeobot Palyno, 258, 55, 2018.

14. ROBERT G.M., SPENCER, GUO W.D., PETER A., RAYMOND T., DITTMAR E. Source and biolability of ancient dissolved organic matter in glacier and lake ecosystems on the Tibetan Plateau. Geochimica et Cosmochimica Acta, 142 (1), 68, 2014. 
15. PIERRE E.,COURTYA P.D., SILVIA C., HELGE N., MORITZ F.L., MIROSLAV V., MARC-ANDRÉ S. Species-dependent partitioning of $\mathrm{C}$ and $\mathrm{N}$ stable isotopes between arbuscular mycorrhizal fungi and their $\mathrm{C} 3$ and $\mathrm{C} 4$ hosts. Soil. Biol. Biochem., 82, 57, 2015.

16. AHMAD K., DAVIES C. Stable isotope $\left(\delta^{13} \mathrm{C}\right.$ and $\delta^{15} \mathrm{~N}$ ) based interpretation of organic matter source and paleoenvironmental conditions in Al-Azraq basin, Jordan. Applied Geochemis, 78, 57, 2017.

17. MÜLLER A., MATHESIUS U. The palaeoenvironments of coastal lagoons in the southern Baltic Sea, I. The application of sedimentary $\mathrm{Corg} / \mathrm{N}$ ratios as source indicators of organic matter. Palaeo-geogr., Palaeo-cli, Palaeo-ecol 145 (3), 13, 1999.

18. WANG Q.S., SONG Y.G., ZHAO Z.J., LI J.J. Color characteristics of Chinese loess and its paleoclimatic significance during the last glacial-interglacial cycle. J.Asian Earth Sci.116, 135, 2016.

19. ANDRÉ D.O.S., ARCHIMEDES P.F. Late Holocene coastal dynamics, climate pulses and low terraces in the coast of the state of São Paulo, southeast, Brazil. J.S.AM. Erath. Sci. 92, 235, 2019.

20. WANG P.K., ZHU Y.H., LU Z.Q., HUANG X., PANG S.J., ZHANG,S. Geochemistry and genesis of authigenic pyrite from gas hydrate accumulation system in the Qilian Mountain permafrost, Qinghai, northwest China. Sci China-Earth Sci, 57, 2219, 2014.

21. DENG J., YIN Y., ZHU W., ZHOU Y. Variations in soil bacterial community diversity and structures among different revegetation types. Front. Microbiol., 9, 2874, 2018.

22. NI G., JIE Z., YUN L . Climate Change Indicated by the Recent Change of Inland Lakes in Northwest China. J. Glacioly \& Geocry, 25 (2), 213, 2003.

23. LIU C.L., CHEN Y.Z., CHEN W.Z., JIAO P.C., YU Y.L., LI S.D. Characteristics and paleoclimatic significance of calcium mirabilite inclusions deposited in the late pleistocene of the Lopnur salt lake. Acta mineralogica sinica, 26 (1), 96, 2006 [In Chinese].

24. LI B.F., CHEN Y.N., CHEN Z.S., LI W.H. Trends in runoff versus climate change in typical rivers in the arid region of northwest China. Quarter. Int., 282, 89, 2012.

25. FU A.H., CHEN Y.N., LI W.H., LI B.F., LI W.H., YANG S.H. Spatial and temporal patterns of climate variations in the Kaidu River Basin of Xinjiang, Northwest China. Quat. Int., 311, 123, 2013.

26. YANG D., PENG Z., LUO C., LIU YI., ZHANG Z.F., LIU W.G., ZHANG P.X. High-resolution pollen sequence from Lop Nur, Xinjiang, China: Implications on environmental changes during the late Pleistocene to the early Holocene[J]. Rev. of Palaeobotany\& Palynology, 192, 35. 2013

27. YUAN G.Y., YUAN L. An approach to the environmental changes in Lop-Nur history. Acta Geographica Sinica, 17, 78, 1998 [In Chinese].

28. MA C.M., WANG F.B., CAO Q.Y., XIA X.C., LI S.F., LI X.S. Climate and environment reconstruction during the Medieval Warm Period in Lop Nur of Xinjiang, China. Chinese Science Bulletin, 19, 119, 2008 [In Chinese].

29. LUO C., PENG Z.C., YANG D., LIU W.G.,ZHANG Z.F., HE J.F., CHOU C.L. A lacustrine record from Lop Nur, Xinjiang, China: Implications for paleoclimate change during Late Pleistocene. J. Asian Earth Sci., 34 (1), 34, 2009.

30. ZHU J., JIA P., NIE Y. Analysis of the ancient river system in Loulan period in Lop Nur region. Science Press, Beijing, 2011.
31. YAN S., MU G.J., XU Y.Q. Quaternary environmental evolution in Lopnur region. Acta micropaleont, 17, 189, 2000.

32. LIU S.Y., DING Y.J., SHANG G., DONG H.,ZHANG Y., LI J., HAN H.D., WANG J., XIE C.W. Glacier retreat as a result of climate warming and increased precipitation in the Tarim river basin, northwest China. Ann. Glaciol, 43 (1), 94, 2006.

33. LI B.Q. Study on yi xun tuntian in the western regions of the western Han dynasty. Study on the western regions, 14 (2), 8, 2003 [In Chinese],

34. GAO X.R., SUN M., LUAN Q.H., ZHAO X.N. The spatial and temporal evolution of the actual evapotranspiration based on the remote sensing method in the Loess Plateau. Sci.Total Environ. 708 ,13511 (4), 2020.

35. CAI Z.Q., ZHANG Y.H., YANG C., WANG S. Land-use type strongly shapes community composition, but not always diversity of soil microbes in tropical China. Catena, 165, 371, 2018.

36. LAI Z.P., MISCHKE S., MADSEN D. Paleoenvironmental implications of new OSL dates on the formation of the "Shell Bar" in the Qaidam Basin, northeastern QinghaiTibetan Plateau. J. Paleolimnology, 51 (2), 202, 2014.

37. HUCK S., HEIMHOFER U., IMMENHAUSER A., WERSERT H. Carbon-isotope stratigraphy of Early Cretaceous (Urgonian) shoal-water deposits: diachronous changes in carbonate-platform production in the northwestern Tethys. Sediment.Geol. 290, 166, 2013.

38. LIANG Y., YU H., ORTIZ J.D., XU X., QIANG X., HUANG H., SHI X., CHEN C. A reconstruction of late Pleistocene relative sea level in the south Bohai Sea, China, based on sediment grain-size analysis. Sedimentary Geology, 43, 282, 2012.

39. LI Y. Rapid and cyclic dust accumulation during MIS 2 in Central Asia inferred from loess OSL dating and grainsize analysis. Sci. Rep. 6, 32365, 2016.

40. EMMERT, E. M. The rapid determination of total nitrogen in soil. Soil Science 58 (4), 289, 2014 [In Chinese].

41. BREMNER J.M., JENKINSON D.S. Determination of organic carbon in soil. J.Soil Sci. 11, 25,1960.

42. ZHANG Y.Y., ZHANG W.H. Automated Analyzer, LOI and other Methods for Determination of Soil Organic Carbon. Applied Mech.\& Materials, 580, 905, 2014.

43. AICHNER B., HERZSCHUH U., WILKES H. Influence of aquatic macrophytes on stable carbon isotope signatures of sedimentary organic matter in lakes on the Tibetan Plateau. Organic Geoch, 41 (7), 711, 2010.

44. YUAN Y.Z., XING L., SHU W. et al. A Preliminary Study on the Determination of Organic Carbon Stable Isotope of Marine Sediment by Element Analyzer-Isotope Ratio Mass Spectrometer. Rock \& Mineral Analysis, 25, 89, 2012.

45. CHEN G.C., ZHENG H.B., LI J.R., XIE X., MEI X. Dynamic control on grain-size distribution of terrigenous sediments in the western South China Sea:Implication for East Asian monsoon evolution. Chinese Science Bulletin, 10, 85, 2008 [In Chinese].

46. FENG Z.G., WANG S.J., HUANG W., LIU J. The provenance of weathering crusts in karst terrains, western hunan province: indication of grain size distribution characteristics of quartz. J. Mineral \& Petrol, 29, 84, 2009.

47. NING K., LI Z.L., WANG N., SUN J.W., SHAO W.W. Spatial Characteristics of Grain Size and Its Environmental Implication in the Badain Jaran Desert. Journal of Desert Research, 37, 202, 2013 [In Chinese]. 
48. ZHI B.D., ZHEN S.L. Wind Erodibility of Aeolian Sand as Influenced by Grain size Parameters. Journal of Soil Water Conservation, 18, 29, 1998 [In Chinese].

49. LIAO X.X., LI S., WANG G.Y., LI Z.L. Grain-size features of aeolian sand on the east coast of Hainan Island and the revealed evolutionary processes of the sedimentary environment. Sciences in Cold and Arid Regions, 6, 79, 2010 [In Chinese].

50. KASHIWAYA K., YAMAMOTO A., FUKUYAMA K. Statistical analysis of grain size distribution in Pleistocene sediments from Lake Biwa, Japan. Quatern Res. 130 (1), $15,1988$.

51. DINARKARAN J., KIRISHNAYYA N. Variations in total organic carbon and grain size distribution, in ephemeral river sediments in western India. Int. J.Sediment Res. 26 (2), 242, 2011.

52. ZHANG J.Q., ZHANG C.L., ZHOU N., MA X.J. Spatial pattern of grain-size distribution in surface sediments as a result of variations in the aeolian environment in China's Shapotou railway protective system[J]. Aeolian Res. 3, 299, 2012.

53. ZHOU Y. The distribution of sediments grain size along the depth in source of the Yangtze River, Tibetan Plateau, China, AGU Fall Meeting, 2017.

54. JANSSON J.K. HOFMOCKEL K.S.The soil microbiomefrom metagenomics to metaphenomics. Curr. Opin. Microbiol., 43, 166, 2018.

55. LUKE J.W., RICHARD H.W., JOSHUA G., JAMES E.P.U., ANU T. The origin of clay-coated sand grains and sediment heterogeneity in tidal flat. Sediment. Geol. 373, 201, 2018.

56. LI Q., FANG X., TAO F.Z. Grain-size Features of Lacustrine Sediments from Chaohu Lake and Its Sedimentary Implications. Scientia Geographica Sinica , 35, 1322, 2015 [In Chinese].

57. ZHAO G.M., YE S.Y., HE L., YUAN H.M., DING X.G., WANG J., EDWARD A.L. Historical change of carbon burial in Late Quaternary sediments of the ancient Yellow River delta on the west coast of Bohai Bay, China. CATENA, 193, 104619, 2020.

58. LIU R., MEI X., ZHANG J., ZHAO D.B. Characteristics of clay minerals in sediments of Hemudu area, Zhejiang, China in Holocene and their environmental significance. China Geology. 2, 10, 2019.
59. LIU R., QIN J.G., MEI X. Sedimentary environment changes of the Ningshao Plain since the later stage of the Late Pleistocene: Evidence from palynology and stable organic carbon isotopes.Quat. Inter, 333, 189, 2014.

60. WANG Z.H., RYVES D.B., LEI S., NIAN X.M., LV Y., TANG L., WANG L., WANG J.H., CHEN J. Middle Holocene marine flooding and human response in the south Yangtze coastal plain, East China. Quat. Sci. Rev. 187, 88, 2018.

61. SHABNAM C., NAYAK G.N., KUMAR T. A. Source, processes and productivity from distribution of surface sediments, Prydz Bay, East Antarctica. Polar Science, 29, 231, 2018.

62. XU H., CHEN J., CUI Z.J., CHEN R.C. Sedimentary facies and depositional processes of the Diexi Ancient Dammed Lake, Upper Minjiang River, China. SedIiment. Geol. 398, 105583, 2020.

63. HUSINECA A., READ.J.F. Cyclostratigraphic and $\delta^{13} \mathrm{C}$ record of the Lower Cretaceous Adriatic Platform, Croatia: Assessment of Milankovitch-forcing. Sediment. Geol. 373, 22, 2018.

64. WANG M.X., PAN X.X., XIA X.F., XI B.D., WANG L.J. Environmental sustainability of bioethanol produced from sweet sorghum stem on saline-alkali land. Biores.Tech. 187, 116, 2017.

65. TEECE M.A., FOGEL M.L. Stable carbon isotope biogeochemistry of monosaccharides in aquatic organisms and terrestrial plants. Organic Geochemistry, 38, 461, 2007.

66. LIANG Y.T., ZHAO H.H., ZHANG X., ZHOU J.H., LI G.H. Contrasting microbial functional genes in two distinct saline-alkali and slightly acidic oil-contaminated sites. Sci.Total. Environ. 487 (15), 275, 2014.

67. CHRISTINE D.S., LAWRENCE G.O., RANDALL D.J., PHILIP R. Plant community composition influences fine root production and biomass allocation in perennial bioenergy cropping systems of the upper Midwest, USA. Biomass Bioenerg. 105, 251, 2017.

68. WERTIN T.M., REE S.C., BELNAP J. C3 and C4 plant responses to increased temperatures and altered monsoonal precipitation in a cool desert on the Colorado Plateau, USA. Oecologia, 177, 998, 2015. 